\title{
In Search of the Way Forward: Implementing the Pedagogical Perspective of English as an International Language in Bulgaria
}

\begin{abstract}
This article examines current ELT in the Bulgarian cultural context and suggests a possible path it may take in the future. It highlights the characteristic features of English pedagogy in Bulgaria and identifies a monocentric approach to the English language, i.e. one which views English as monolithic and homogeneous rather than as pluralistic and diverse. The main argument is that such an approach runs counter to the current pluralistic views about the nature of English and its pedagogy, as well as to the linguistic needs of present-day Bulgarian learners of English, who are increasingly likely to use the language for communication with speakers of different world Englishes. Therefore, this contribution argues for the need to broaden the focus of traditional English pedagogy in Bulgaria so as to incorporate the linguistic, cultural and functional diversity of English. It proposes a pedagogical framework, suitable for tertiary advanced-level education, in which students pass through three stages when encountering the variability of the language (awareness-raising, experiential and analytic stage), and gives examples of specific learning activities which can be employed at each stage.
\end{abstract}

Keywords: English pedagogy, teaching English as an international language, English language teaching in Bulgaria, teaching English at tertiary level

\section{Iskanje poti naprej: Uresničevanje pedagoške perspektive angleščine kot mednarodnega jezika v Bolgariji}

\section{POVZETEK}

Članek proučuje poučevanje angleškega jezika v bolgarskem kulturnem kontekstu in predlaga možno pot, ki bi jo lahko ubralo v prihodnosti. Izpostavljene so značilnosti angleške pedagogike $\mathrm{v}$ Bolgariji. Opredeljen je monocentrični pristop $\mathrm{k}$ angleškemu jeziku, to je tisti, ki angleščino vidi kot monolitno in homogeno, ne pa kot pluralistično in raznoliko. Glavni argument sedanje razprave je, da je tak pristop v nasprotju s sedanjimi pluralističnimi pogledi na naravo angleščine in njene pedagogike, kakor tudi z jezikovnimi potrebami današnjih bolgarskih učencev angleščine, ki vse pogosteje uporabljajo jezik za komunikacijo z govorci različnih svetovnih jezikov. Prispevek ugotavlja, da je treba razširiti središče tradicionalne angleške pedagogike v Bolgariji tako, da se vključi jezikovna, kulturna in funkcionalna raznolikost angleščine. Predlagan je pedagoški okvir, primeren za terciarno izobraževanje na višji stopnji, v katerem učenci preidejo skozi tri stopnje, ko se srečujejo z variabilnostjo jezika (stopnja ozaveščanja, izkustvena in analitična stopnja). Podani so primeri posebnih učnih dejavnosti, ki jih je mogoče uporabiti na vsaki stopnji.

Ključne besede: angleška pedagogika, poučevanje angleščine kot mednarodnega jezika, poučevanje angleščine v Bolgariji, poučevanje angleščine na tretji stopnji 


\section{Introduction}

The internationalisation of present-day English is an indisputable reality. The growth of the language into a global means of expression and interaction has altered its sociolinguistic character to a great extent. Today, English plays an important role in different globalised spheres of social life, such as international relations, travel, tourism, science and technology, and serves to connect people that are otherwise separated from each other due to linguistic and cultural barriers. In its function as a global communicative tool it is frequently employed by members of different lingua-cultural communities who may adjust it to suit their specific interactional and identity construction needs. As a result, the shapes that English takes these days tend to proliferate and the language emerges as a family of different Englishes rather than as a single homogeneous entity. Indeed, diversity is a defining characteristic feature of English today.

The new sociolinguistic character of global English is largely the reason why views about both what it is and how it should be taught have changed through time. Descriptions of the nature of English have witnessed a major ideological shift from monocentric to pluricentric views, that is, approaches which regard the language as uniform and monolithic have been superseded by ones that emphasise its plurality, diversity and heterogeneity. For instance, within the Kachruvian model of world Englishes (1985) the language is considered to be a collection of different varieties functioning in specific contexts of acquisition and use. The contexts themselves can be subsumed under three broad categories: inner circle (traditional native speaker contexts where English is acquired as a first language, such as the UK, US, Australia, New Zealand), outer circle (multilingual non-native speaker territories where English is used as a second, often official language, such as India, Nigeria, the Philippines) and expanding circle (non-native speaker areas where English is learned as a foreign language, such as Bulgaria, Poland, Japan). Clearly, this classification treats English as pluralistic by highlighting its diversity on a national level. It is a divergence perspective which brings to the fore the manner in which national varieties of English differ from one another in terms of structural features, pragmatic norms as well as functional uses.

Another strand of analysis which takes a pluralistic view of English and stresses the diversity it displays in terms of linguistic features and norms of use is research into English as a lingua franca (ELF), that is, the employment of the language for communication among speakers of different linguistic and cultural backgrounds (Seidlhofer 2001, 2004; Jenkins 2002, 2006; House 2003; Mauranen 2010). The main argument of this analytic perspective has been that the linguistic codes used in lingua franca international communicative encounters often vary on different levels (phonology, grammar, lexis, pragmatics), displaying features which diverge in one way or another from the well-established native speaker patterns and norms. More recently, some scholars have emphasised even more the heterogeneity and fluidity of the English used in lingua franca contexts by claiming that the forms employed in such cases rarely pre-exist interaction, and are negotiated and constructed during the communicative process itself (Canagarajah 2007; Friedrich and Matsuda 2010). Lingua franca interaction usually brings together speakers of diverse Englishes, who often need to apply negotiation strategies to cope with any linguistic and cultural differences they have and then construct 
a shared communicative code. What comes to the fore in this line of thought is a view of English as a contextualised construct emerging in particular interactional encounters and taking diverse shapes across situations depending on the specific set of participants, their lingua-cultural background and expectations about appropriate language use.

Apart from descriptions of the nature of English, beliefs about the manner in which it should be taught have also undergone significant changes. It could be argued that views about what constitutes efficient English pedagogy have also moved beyond monocentrism towards plurality. Monocentric approaches to English language teaching (ELT), which remain too close to native speaker linguistic codes and communicative patterns and require that the exclusive focus should be on the Anglo-American form of English and its cultural conventions, have been called into question (Modiano 2001; McKay 2003; Baker 2012; Kirkpatrick 2014). There have been suggestions for broadening the scope of traditional English pedagogy so as to take into account the plurality of English. A number of scholars have stressed the importance of teaching English as a truly global language, taking into account the fact that it is diverse in forms, users and functions (McKay 2002; Sharifian 2009; Alsagoff et al. 2012; Matsuda 2012; Zacharias and Manara 2013; Canagarajah 2014; Marlina and Giri 2014). It all testifies to the emergence of a new pedagogical English as an international language (EIL) perspective which, as Matsuda $(2018,25)$ points out, "acknowledges the linguistic, functional, and cultural diversity associated with the English language today", and attempts to incorporate it into the classroom. Indeed, the hallmark of this more inclusive pedagogical approach is highlighting the need to expose students to the variability of English, encourage them to adopt positive attitudes towards its various forms as well as urge them to develop skills to deal with the complexity of its present-day use.

The discussion up to this point clearly shows that there have been calls for altering approaches to teaching English in an attempt to capture its new sociolinguistic realities. However, studies conducted in different parts of the world, especially in Kachru's expanding circle, continue to report the existence of some discrepancies between the changed discourse about ELT and what actually happens in the classroom (Matsuda 2002, 2003; Park and Kim 2014). Such research tends to indicate that teaching practices remain largely traditional by disregarding the emerging pluralistic views about English pedagogy and adhering to a monocentric approach which lays stress on the Kachruvian inner circle with its speakers and cultures, and gives priority to British or American English. This article adds to the discussion by presenting the Bulgarian cultural context as another example of a situation in which there appears to be a gap between the new pluralistic perspectives on English pedagogy and actual ELT policy and practice.

Despite the fact that ELT in Bulgaria has been revised and transformed to embrace more modern pedagogical perspectives, such as communicative language pedagogy and intercultural awareness building, it seems to be traditional in its predominantly monocentric approach to the language with a focus on inner circle contexts, the Anglo-American form of English and its cultural conventions. This could be explained by the fact that Bulgaria is a typical expanding circle context in Kachru's (1985) terminology, and is therefore normdependent, i.e. it uses the inner circle as a framework of reference. It is common practice in 
expanding circle situations to use British/American educated native speaker norms as points of reference in acquiring and using English. However, the main argument of this paper is that monocentric pedagogical practices run counter to the needs of present-day Bulgarian learners of English, who are increasingly likely to use the language for communication with speakers of different world Englishes. Indeed, they should be ready to meet the diversity of English in the age of globalisation. Therefore, the present contribution argues for the need to incorporate an EIL perspective into traditional ELT in Bulgaria. This new element should stress the globalisation and diversification of English, and equip students with the knowledge, skills and attitudes they need to deal with the complexity of English language use today. It should take into account the existence of world Englishes and the employment of English as a lingua franca. It is important to note that in the current article the term 'English as an international language' (EIL) is used to describe the expanded scope of English as a global language associated with its spread around the world and the increase in its linguistic and functional variability, whereas 'world Englishes' (WE) and 'English as a lingua franca' (ELF) both serve more specific purposes: the former refers to the different varieties of English existing in the world, the latter to a specific use of the language in communicative encounters which involve speakers of diverse lingua-cultural backgrounds.

The following discussion focuses on the dominant characteristics of present-day ELT in Bulgaria and attempts to suggest a possible path it may take in the future. First, this article gives an overview of current English language pedagogy in the Bulgarian cultural context, specifying its features and providing a snapshot of problematic points. Then, it proposes some means through which traditional pedagogical practices could be revised so as to address as well as acknowledge the internationalised and diversified nature of English today. This paper presents a way of broadening the traditional scope of the Bulgarian English language classroom in tertiary advanced-level education and incorporating the plurality of English by introducing a three-part teaching framework. According to this framework, students' encounter with the linguistic and cultural diversity of English goes through three stages: awareness-raising, experiential and analytic. The present discussion also gives examples of specific teaching practices or learning activities that can be used at each stage.

\section{ELT in Bulgaria - An Overview}

ELT in Bulgaria has undoubtedly gone through a process of transformation in the past 30 years or so. A survey of its current state will show that it has been modernised to a great extent in an attempt to offer Bulgarian learners a chance to join the global exchange of ideas, products and services. Pedagogical practices have incorporated recent popular developments in foreign language teaching methodology laying emphasis on communication, authentic language use, developing the four language skills in an integrated manner, and assessment in terms of language abilities and skills, to name but a few. Communicative language pedagogy has come to reign supreme (for a description of salient features, see Nunan 1991; Brown 1994; Richards 2006). This has led to an increased emphasis on teaching English in a communicative manner. Priority has been given to appropriate language use in different interactional contexts. As a result, pedagogical goals have been expanded to include not just mastery of the linguistic code (i.e. knowledge of grammar, vocabulary, phonetic rules) and 
skills of accurate language usage, but also knowledge of how to use language appropriately in specific situations (i.e. ability to employ language in such a way that contextually relevant factors such as setting, interlocutor, goal of interaction, topic, etc. are taken into account). Indeed, there has been a shift from linguistic towards communicative competence as the ultimate goal of English language teaching. Attempts at specifying its components and identifying the most relevant means of developing them in the classroom were already at hand in the 1990s.

An illustrative example of endeavours to describe the pedagogical goal of communicative competence is the "Entrance-Exit Level" (1993-1995) collaborative project between Sofia University "St. Kliment Ohridski" and the Bulgarian Ministry of Education and Science. It aimed at adapting the Council of Europe's "Threshold Level 1990" document (van Ek and Trim 1991) so that it would meet the needs of Bulgarian learners and be applicable in Bulgarian primary and secondary school classrooms. The "Entrance-Exit" publications (Patev et al. 1993; Patev et al. 1995) proposed a model of communicative competence consisting of three elements (linguistic competence, subdivided into structural and functional, sociocultural competence and strategic competence) and presented specific ways of developing them. This involved listing particular language functions, notions, text types and linguistic material which learners needed to master. Emerging as typical communicative syllabi, these publications contributed to the spread and implementation of communicative language pedagogy on Bulgarian soil. Almost alongside the "Entrance-Exit Level" endeavour, another FinnishBulgarian joint project was carried out. The "Consulting Services for Foreign Language Training Upgrading in Bulgarian Schools" (1994-1995) research project of the University of Helsinki and the Bulgarian Ministry of Education and Science aimed at assessing foreign language education in the Bulgarian classroom and offering recommendations as to how it could be brought into line with European standards and recent foreign language teaching methodologies. Some of the recommendations that were made involved specific suggestions for strengthening the communicative element in the Bulgarian classroom: e.g. introducing constructivist pedagogy, laying emphasis on authentic communication, providing exposure to real-life practical topics, developing the ability to function in unrehearsed contexts, engaging students in communicative activities such as pair work and role plays, etc. (see Tella, YliRenko, and Mononen-Aaltonen 1996, 92-110). It could be argued that communicative language pedagogy has become an important feature of ELT in Bulgaria as a result of efforts such as the abovementioned projects. Today, the Common European Framework of Reference for Languages (Council of Europe 2001) with its model of communicative competence, consisting of linguistic, sociolinguistic and pragmatic elements, as well as levels of language proficiency, is used as a reference point in the process of teaching and assessing foreign languages.

Apart from the adoption of communicative language pedagogy, another notable transformation that ELT in Bulgaria has witnessed is the expansion of the teaching target itself to include the development of intercultural communicative competence in students (Byram 1997; Georgieva 2002), and thus the ability to function well in communicative contexts which bring together speakers of different linguistic and cultural backgrounds. This new pedagogical goal involves encouraging students to acquire skills in identifying and coping with cultural differences in 
language use, worldview and behaviour. The addition of the intercultural component to the list of teaching goals has been reflected in the publication of local English language textbooks which give priority to the idea of cultural variability. For example, locally published textbooks such as $A$ World of English (Grozdanova et al. 1996), Moving On (Grozdanova, Georgieva, and Nedkova 1998) and Links (Rangelova and Grozdanova 2001) contain tasks which engage learners in the activities of intercultural communication, identifying similarities and differences between cultures and sharing one's own culture with representatives of others (see Grozdanova 2002). The publication of such textbooks has been accompanied by the creation of a cultural studies syllabus (Davcheva and Docheva 1998) whose main argument is that alongside linguistic competence, students should also develop intercultural communicative competence. Aimed at supplementing a typical English language course, it specifies the skills one needs to develop in order to be able to deal with cultural diversity: e.g. reading and listening in a critical way, comparing and contrasting cultural content, research and ethnographic skills as well as ability to interpret standpoints different from one's own (Davcheva and Docheva 1998, 14). More recently, there have been explicit calls for integrating the development of intercultural communicative competence into both secondary and tertiary education (Tsvetkova 2012, 2018). In addition, specific suggestions for pedagogical frameworks intended to facilitate the acquisition of such competence have been made. For instance, Tsvetkova (2013) proposes a teaching framework targeted towards the inclusion of intercultural communicative competence at secondary level. The framework lays considerable emphasis on the development of intercultural skills, tolerance of cultural difference and ability to establish links between one's own culture and the culture of the foreign language(s) being learned (Tsvetkova 2013, 314). Likewise, Catalan, Stoicheva and Tsvetkova's (2013) framework designed to be applied at tertiary level gives priority to the development of intercultural knowledge, skills and attitudes in the domains of theory, texts and interpersonal relationships.

All the developments in ELT reported in the preceding paragraphs have found their place in the current national curricula in English as a foreign language for secondary education in Bulgaria (Ministry of Education and Science 2020). They lay stress on teaching English in a communicative way, give priority to real-life language use in context and aim at stimulating students to acquire both linguistic and sociocultural competences. Another objective of the curricula is raising learners' intercultural awareness and urging them to become openminded and tolerant with respect to cultural diversity. The specified means of achieving these objectives involve an interactive, task-based approach which engages learners in authentic interaction, helps them acquire the four language skills of reading, listening, speaking and writing in an integrated manner and urges them to develop critical thinking.

The analysis so far indicates that ELT in Bulgaria has been transformed in such a way that it is in line with modern language teaching approaches which give priority to the communicative idea and interculturality to a significant degree. Nevertheless, it appears that English pedagogy in the Bulgarian cultural context continues to be traditional in its predominantly monocentric approach to the language. English tends to be regarded as uniform, monolithic and homogeneous, rather than as diverse, pluralistic and heterogeneous. This approach can be uncovered in the current national English language curricula for secondary education (Ministry of Education and Science 2020). Their rhetoric clearly displays a monocentric stance. For 
instance, one of the goals of ELT specified in the highest-level B2.1 curriculum is connected with encouraging students to adopt positive attitudes towards the English language and its culture (Ministry of Education and Science 2018, 7). This indicates that both the language and its cultural background are approached in the singular. Another objective associated with ELT in the curriculum states that when helping students to acquire intercultural knowledge, skills and attitudes in the process of learning English, stress should be laid on English-speaking countries and more specifically, the UK and US (Ministry of Education and Science 2018, 8). The act of reducing the cultures of English to just two of its native speaker contexts also reveals a monocentric perspective on the language. It could be argued that this approach to English goes beyond the boundaries of the national curricula and reaches the English language classroom where inner circle conventionalised norms, the Anglo-American form of English and its cultural aspects tend to constitute the usual focus of attention. A possible explanation for this is related to the fact that state schools have an obligation to follow the requirements of the English language curricula and choose from a fixed set of teaching materials carefully selected and approved by the Ministry of Education and Science to meet those requirements. As a result, the monocentric approach of the curricula discussed above can easily permeate the teaching practices in the English language classroom.

A qualitative analysis of two randomly selected textbooks accepted for use in the higher levels of secondary schools by the Ministry of Education and Science can serve to illustrate the aforementioned monocentric approach which gives priority to Anglo-American English and its culture, and treats the language as monolithic. For instance, Teen Zone (Petkova and Spasova 2020), a B1.1 textbook for the eleventh and twelfth grades, clearly aims at exposing learners to the widely accepted standard Anglo-American grammatical and lexical norms. What comes to the fore is its significant focus on British and American culture, which appear to be collectively regarded as the target culture of the English language. This focus is accompanied by an increased emphasis on providing students with the opportunity to investigate aspects of their own Bulgarian culture and learn how to share them with the rest of the world. Indeed, it seems that in the textbook the development of intercultural skills takes place predominantly on the basis of a three-part distinction: the UK, US and Bulgaria. Likewise, Jetstream (Harmer, Revell, and Vasileva 2020), a B2.1 textbook for the eleventh and twelfth grades, focuses on the well-established conventionalised Anglo-American grammatical and lexical norms. In terms of cultural content, it keeps the traditional presentation of British and American culture. In addition to this, the textbook expands the perspective to include a global focus and present students with information about various cultural practices and traditions from different parts of the world. Indeed, the textbook sets itself the clear goal of familiarising students with the cultural diversity existing on a global scale. However, in the process of expanding the cultural focus, English seems to be assigned the role of acting mainly as a suitable tool to access and learn about this diversity. It should be noted that there is little explicit information about the cultural, linguistic and functional diversity existing within the scope of the English language today. For instance, there is hardly any information about how English varies in terms of forms and norms of use, how it becomes embedded in specific cultural contexts and how different sociocultural assumptions tend to shape its use. As a result, English emerges as monolithic and uniform, which brings to the fore a typically monocentric approach to the language. 
Research conducted in the Bulgarian cultural context has addressed the impact that the focus on the Anglo-American form of English and its cultural aspects might have on learners' idea about the nature of present-day English and its scope. For example, in an investigation carried out among first-year university students it was found that learners' view about the character of English is abstract, vague and to a large extent incomplete (Dimova 2018). The findings that emerge from the analysis indicate that the informants adopt a monocentric approach to the language by restricting it to two of its native speaker varieties: British and American English. They assess these two forms of English very positively, consider them suitable as a framework of reference in the process of acquiring English, and can describe them in detail. The results also show that the study participants know very little about other varieties of English, and often evaluate these other variants in negative terms. Indeed, what comes to the fore is a perspective on English that treats it as being synonymous with Anglo-American English, a view which is incomplete and fails to take into account the tremendous diversity that the language displays today. A key issue which emerges is that students who have such a reduced, incomplete idea of global English might be confronted with serious problems when they encounter the linguistic and functional diversity of English in real-life communicative exchanges. As already mentioned, communicative encounters in English today often bring together speakers of different Englishes. Indeed, as Matsuda $(2018,29)$ argues, learners of English who have an abstract, limited idea of global English and have not been exposed to its variability "may be startled, surprised, confused, overwhelmed or feel unprepared for such situations". All this might prevent them from taking an active and efficient part in communication through the use of English.

A wide variety of reasons as to why Bulgarians may decide to learn English can be uncovered. Their motivation ranges from integrative, i.e. joining an English-speaking community, to instrumental, i.e. pragmatic reasons such as social advancement, better career opportunities, getting access to information and social domains of international importance, for instance, international travel, business, science, education, etc. (see Chavdarova, Penkova, and Tsvetkova 2013; Markova 2016; Dimova 2018; Markova and Yaneva 2020). It could be argued that what stands out against this diversity of specific reasons for learning English is an overarching common motivation related to a desire to participate in the global marketplace of ideas, products and services, participation which in itself often involves international lingua franca communication across linguistic and cultural boundaries. In such communicative encounters Bulgarian students of English are likely to use English not just for communication with speakers of Anglo-American English, but also with speakers of a wide range of other world Englishes. Therefore, the current paper argues for the need to broaden Bulgarian learners' predominantly monocentric idea of English by exposing them to its diversity within the boundaries of the English language classroom itself. A possible means of achieving this is incorporating an EIL perspective into traditional English pedagogy. This article equates the act of including an EIL element into traditional ELT with expanding the monocentric focus on Anglo-American English and its cultural aspects, and providing opportunities for students to encounter the linguistic and functional variability of the language even within the four walls of the classroom.

It should be noted that the present contribution does not suggest that the traditional focus on Anglo-American English should be dispensed with altogether. British and American 
English are well-established in the Bulgarian cultural context, and are used effectively as an instructional model and framework of reference in the process of teaching/learning English. In addition, Bulgarian students of English have been repeatedly shown to have positive attitudes to British and American English (Dimitrova 2011; Georgieva 2011; Dimova 2017). As a result, the stance adopted in the current discussion is that the transformation of traditional teaching practices should not get rid of the exposure to Anglo-American English, but should expand the pedagogical focus by incorporating world Englishes and the use of English as a lingua franca - two key elements which illustrate the linguistic, cultural and functional diversity of present-day English and which are likely to be an essential part of Bulgarian learners' communicative encounters in English. The next section suggests possible means of broadening the scope of traditional English classes by presenting a three-stage framework through which the linguistic, cultural and functional variability of the language can be given priority.

\section{Towards Introducing Diversity into the Bulgarian English Language Classroom}

The need to expose students to the linguistic, sociocultural and functional diversity of English as well as encourage them to build the skill of coping with this variability is a recurrent claim in the literature on the status of English as an international language and its implications for pedagogical practices (Marlina 2014). A growing body of research is engaged in the design and construction of materials, curricula and frameworks for teaching English as an international language (Brown 2012; D’Angelo 2012; McKay 2012; Sharifian and Marlina 2012). The present article contributes to this literature by introducing a comprehensive threepart pedagogical framework which can be incorporated into English classes in the Bulgarian cultural context to provide students with knowledge and competences for dealing with the variability and complexity of present-day English (for a similar step-by-step approach to raising English language teachers' awareness of English as an international language, see Bayyurt and Sifakis 2017). It should be noted that the proposed model may be applied in English classes at tertiary education, where language curricula in English tend to be more flexible and less fixed in comparison with those in secondary education. The framework is especially suitable for tertiary students of philology who aim to become teachers or language experts able to function in different spheres of social life. In addition, it is readily applicable in classes involving more advanced learners of English, such as 'independent users' and 'proficient users' according to the Common European Framework of Reference for Languages (Council of Europe 2001), since it aims not only to raise learners' awareness of the plurality of English, but also to engage them in specific activities which require that they explore this diversity and reflect on their experience with respect to coping with it. Indeed, the stance adopted in the present discussion is that advanced students of English should take at least three steps when approaching the variability of English: they should learn about it, experience it and then reflect on it. This three-stage approach should help them develop a more specific and detailed idea about the scope of global English and equip them with the skills necessary for functioning well in its increasingly more complex situations of use. Learners' encounters with the diversity of English should pass through the following stages: 
1. awareness-raising stage: students are exposed to the linguistic, cultural and functional diversity of English;

2. experiential stage: students engage in activities which help them gain hands-on experience with respect to coping with the variability of English;

3. analytic stage: students reflect on their encounter with the diversity of English so as to develop critical, analytic skills and be able to deal with the complexity of English on their own.

In essence, Stage One aims to raise students' awareness of the nature and status of English as a pluralistic language. It involves engaging students in activities that urge them to acquire knowledge about the diverse character of present-day English. During this stage, learners can be exposed to materials (scholarly research, non-fiction texts, videos, lectures, interviews, etc.) which in one way or another bring to the fore the diversified nature of English. The materials should be carefully selected to provide students with information about the spread of English worldwide, its current presence in various domains such as international travel, politics, education, science and technology, as well as its typical varieties, contexts of acquisition/use and some common functions it performs.

Indeed, exposing learners to different varieties of English is a crucial factor in raising their awareness of the plurality of English. Therefore, they should read about the diverse shapes that English takes in different cultural contexts, not only native, but also non-native. Apart from British and American English, students should learn about other world Englishes such as Australian, New Zealand, South African, Indian English, etc. When reading and discussing specific texts about varieties of English, they should pay special attention to variation on the levels of phonology, grammar, lexis and pragmatics.

Furthermore, the analysis of some typical contexts of English language acquisition and use should also go beyond the traditional native speaker inner circle contexts (where more often than not the language is acquired as a mother tongue and is used for a wide range of both formal and informal purposes) to include examples of outer circle contexts (where English is acquired as an additional language and often serves important functions as a link language in a multilingual environment) and expanding circle contexts (where English is learned as a foreign language and is used mostly for international communication across national boundaries). Indeed, special emphasis should be laid on the employment of English as a lingua franca in both intra- and international contexts among speakers of diverse lingua-cultural backgrounds. Students should be made aware of the typical features of such communicative encounters (e.g. employment of diverse English varieties, presence of codeswitching, code-mixing and translanguaging practices, transfer of mother tongue elements, etc.) and the way in which the form of English is frequently subjected to negotiation. Learners may be exposed to contextual phenomena which lead to variability in such contexts (e.g. the social background of the participants, the topic of discussion, the existence of cross-cultural variation in communicative expectations and conduct, etc.) as well as negotiation strategies which might be used to overcome any linguistic and cultural differences. A possible means of putting all this into practice is encouraging students to read different scholarly articles or non-fiction texts, as well as watch videos which discuss the characteristics of lingua franca 
use. Engaging learners in a discussion of sociolinguistic research which explains how different social factors lead to linguistic variability in specific communicative contexts can also serve a useful function.

During the experiential Stage Two, students perform activities which provide them with the opportunity to understand how the diversity of English functions in real life and get practical experience when it comes to dealing with it. Suitable tasks which learners can perform at this stage are reading as well as discussing specific texts which are written in different world Englishes (e.g. journalistic articles, online social network discourse, etc.), and then exploring variation on the level of grammar, lexis and pragmatics. They may analyse variation on the level of pronunciation by listening to speakers with different accents. Another activity which students may undertake is doing ethnographic research of various communities characterised by differences in lingua-cultural background and exploring their use of English. Such tasks will improve students' understanding of how English may become embedded in specific sociocultural communities, and how culturally marked beliefs about what constitutes appropriate communicative behaviour might affect the shape that English takes. In addition, students may be asked to carry out tasks which involve real-life online or offline communication in lingua franca contexts. This will give them the chance to put into practice the knowledge about lingua franca use which they have acquired during Stage One.

The analytic Stage Three is aimed at engaging students in reflective tasks with respect to their encounters with the variability of English. For example, students may be asked to reflect upon their performance in real-life interactions. They may gather examples of online and offline situations in which they use English as a lingua franca and analyse their features and both positive and negative aspects. Students should pay special attention to any problematic cases, such as breakdowns in communication, and search for solutions to the identified problems through improving their strategy use. All this should help students develop analytic/critical skills, enhance their independence as learners and make them better prepared to get to grips with the complexity of English on their own. Indeed, there is no single pedagogical model which can expose students to the diversity of English in all its shapes and forms. Therefore, classroom practices should equip learners with the skills of autonomous functioning and decision making in the increasingly more varied and unpredictable situations of English language use.

\section{Conclusion}

This article focused on the diversified nature of present-day English and traced arguments for a shift from monocentric to pluricentric approaches towards its nature and teaching. It noted the existence of a gap between the pluralistic discourse about English and teaching practices in the Bulgarian cultural context. It provided an overview of ELT in Bulgaria and highlighted its monocentric approach which treats English as a monolithic, homogeneous entity and gives priority to its Anglo-American form and cultural conventions. The present discussion thus argued for the need to expand the traditional focus of English pedagogy in light of the changing linguistic needs of Bulgarian learners, who are likely to communicate with speakers of world Englishes in the age of globalisation. In relation to this, a framework intended to 
broaden the scope of traditional pedagogical practices was proposed. It involves incorporating an EIL perspective which lays stress on the linguistic, cultural and functional diversity of English, and urges students to pass through three stages when encountering its variability: awareness-raising, real-life experience and analysis. In this way, the proposed model aims to encourage students to develop a more detailed and comprehensive view of global English.

Further research might focus on the application of the proposed framework in the context of the tertiary English language classroom in Bulgaria. It is important to examine issues related to the possible reception it gets from teachers and students, which in its part will provide valuable information as to how the model might be refined to increase its efficiency. The idea of teaching English as an international language and addressing its diversity is a relatively recent phenomenon. It will take time to test the applicability of the proposed new EIL pedagogical frameworks. However, taking into account the opinions of learners and teachers - the two groups which are directly involved in the application of the models - will speed the process up.

\section{References}

Alsagoff, Lubna, Sandra Lee McKay, Guangwei Hu, and Willy Renandya. 2012. Principles and Practices for Teaching English as an International Language. New York: Routledge.

Baker, Will. 2012. "Global Cultures and Identities: Refocusing the Aims of ELT in Asia through Intercultural Awareness." In Innovating EFL Teaching in Asia, edited by Theron Muller, Steven Herder, John Adamson, and Philip Brown, 23-34. Basingstoke: Palgrave Macmillan.

Bayyurt, Yasemin, and Nicos Sifakis. 2017. “Foundations of an EIL-aware Teacher Education.” In Preparing Teachers to Teach English as an International Language, edited by Aya Matsuda, 3-18. Clevedon: Multilingual Matters.

Brown, H. Douglas. 1994. Teaching by Principles: An Interactive Approach to Language Pedagogy. New York: Longman.

Brown, James. 2012. "EIL Curriculum Development." In Principles and Practices for Teaching English as an International Language, edited by Lubna Alsagoff, Sandra Lee McKay, Guangwei Hu, and Willy Renandya, 147-67. New York: Routledge.

Byram, Michael. 1997. Teaching and Assessing Intercultural Communicative Competence. Clevedon: Multilingual Matters.

Canagarajah, Suresh. 2007. "Lingua Franca English, Multilingual Communities, and Language Acquisition.” The Modern Language Journal 91: 923-39. https://doi.org/10.1111/j.1540-4781.2007 .00678.x.

—. 2014. "In Search of a New Paradigm for Teaching English as an International Language." TESOL Journal 5 (4): 767-85. https://doi.org/10.1002/tesj.166.

Catalan, Zelma, Maria Stoicheva, and Nikolina Tsvetkova. 2013. "Translating and Mediating between Cultures: The Bulgarian Experience within the PICT Project." In Language, Identity and Culture in Language Education. Edited Volume of the 20th ICC Annual Conference 2013, 57-63. Sofia: British Council and Macmillan.

Chavdarova, Albena, Rossitza Penkova, and Nikolina Tsvetkova. 2013. "School Leavers' Attitudes to, Evaluation of and Perspectives on Language Learning.” Foreign Language Teaching 40 (1): 27-38.

Council of Europe. 2001. Common European Framework of Reference for Languages: Learning, Teaching, Assessment. Cambridge: Cambridge University Press.

D’Angelo, James. 2012. "WE-Informed EIL Curriculum at Chukyo: Towards a Functional, Educated, Multilingual Outcome." In Principles and Practices of Teaching English as an International Language, edited by Aya Matsuda, 121-39. Bristol: Multilingual Matters. 
Davcheva, Leah, and Yana Docheva. 1998. Branching Out. A Cultural Studies Syllabus. Sofia: British Council and Tilia.

Dimitrova, Snezhina. 2011. "English as a Lingua Franca and the Teaching of English Pronunciation at Sofia University in Bulgaria." In English Studies in a European/Global Context: Current Issues, Future Trends, edited by Zoran Ančevski and Rumena Bužarovska, 63-72. Skopje: Blaže Koneski Faculty of Philology.

Dimova, Irena. 2017. "English as an International Language: Speakers' Attitudes and Their Implications for Teaching Practices." In New Paradigms in English Studies: Language, Linguistics, Literature and Culture in Higher Education, edited by Emilia Slavova, Bozhil Hristov, Jonathan McCreedy, Rositsa Ishpekova, Alexandra Glavanakova, Nelly Yakimova, and Angel Igov, 67-81. Sofia: "St. Kliment Ohridski" University Press.

—. 2018. "English as an International Language and the Attitudes in the Bulgarian Cultural Context." Sociolinguistic Issues: Social Processes and Their Impact on Language 13: 390-97.

Friedrich, Patricia, and Aya Matsuda. 2010. "When Five Words are not Enough: A Conceptual and Terminological Discussion of English as a Lingua Franca." International Multilingual Research Journal 4: 20-30. https://doi.org/10.1080/19313150903500978.

Georgieva, Maria. 2002. “On Developing Intercultural Communicative Competence in EFL Learners.” In Smaller Languages in the Big World: Sociolinguistics and FLT, edited by Desmond Thomas and Maria Georgieva, 146-59. Sofia: British Council/Lettera Publishers.

-. 2011. Global English in Bulgarian Context. Varna: Silueti Publishing House.

Grozdanova, Lilyana. 2002. "Cultural Diversity in a Unifying World - A New Challenge for English Textbook Writers." In Smaller Languages in the Big World: Sociolinguistics and FLT, edited by Desmond Thomas and Maria Georgieva, 126-45. Sofia: British Council/Lettera Publishers.

Grozdanova, Lilyana, Maria Georgieva, and Marieta Nedkova. 1998. Moving On. Plovdiv: Lettera.

Grozdanova, Lilyana, Maria Georgieva, Marieta Nedkova, Nellie Mladenova, and Diana Vesselinova. 1996. A World of English. Plovdiv: Lettera.

Harmer, Jeremy, Jane Revell, and Niya Vasileva. 2020. Jetstream: Student's Book for the 11th-12th Grades (B2.1 CEF). Sofia: Prosveta and Helbling Languages.

House, Juliane. 2003. "English as a Lingua Franca: A Threat to Multilingualism?” Journal of Sociolinguistics 7 (4): 556-78. https://doi.org/10.1111/j.1467-9841.2003.00242.x.

Jenkins, Jennifer. 2002. "A Sociolinguistically Based, Empirically Researched Pronunciation Syllabus for English as an International Language." Applied Linguistics 23 (1): 83-103. https://doi.org/10.1093 /applin/23.1.83.

—. 2006. "Points of View and Blind Spots: ELF and SLA." International Journal of Applied Linguistics 16 (2): 137-62. https://doi.org/10.1111/j.1473-4192.2006.00111.x.

Kachru, Braj. 1985. "Standards, Codification and Sociolinguistic Realism: The English Language in the Outer Circle." In English in the World: Teaching and Learning the Language and Literatures, edited by Randolph Quirk and Henry Widdowson, 11-30. Cambridge: Cambridge University Press.

Kirkpatrick, Andy. 2014. "Teaching English in Asia in Non-Anglo Cultural Contexts: Principles of the 'Lingua Franca Approach'." In The Pedagogy of English as an International Language: Perspectives from Scholars, Teachers, and Students, edited by Roby Marlina and Ram Giri, 23-34. London: Springer International Publishing.

Markova, Zarina. 2016. "Straight from the Horse's Mouth: Motivation to Learn English.” E-Newsletter. Bulgarian English Teachers' Association 22: 36-49. https://www.beta-iatefl.org/wp-content/uploads /2016/06/BETA_E-Newsletter_March_April_2016.pdf.

Markova, Zarina, and Dessislava Yaneva. 2020. "The Motivation of University Students of International Relations to Learn English.” English Studies at NBU 6 (1): 5-28. https://doi.org/10.33919/esnbu.20 .1.1.

Marlina, Roby. 2014. "The Pedagogy of English as an International Language (EIL): More Reflections and Dialogues." In The Pedagogy of English as an International Language: Perspectives from Scholars, Teachers, and Students, edited by Roby Marlina and Ram Giri, 1-19. London: Springer International Publishing. 
Marlina, Roby, and Ram Giri. 2014. The Pedagogy of English as an International Language: Perspectives from Scholars, Teachers, and Students. London: Springer International Publishing.

Matsuda, Aya. 2002. "Representation of Users and Uses of English in Beginning Japanese EFL Textbooks." JALT Journal 24 (2): 182-216.

—. 2003. "Incorporating World Englishes in Teaching English as an International Language." TESOL Quarterly 37 (4): 719-29. https://doi.org/10.2307/3588220.

- 2012. Principles and Practices of Teaching English as an International Language. Bristol: Multilingual Matters.

—. 2018. "Is Teaching English as an International Language All about Being Politically Correct?" RELC Journal 49 (1): 24-35. https://doi.org/10.1177/0033688217753489.

Mauranen, Anna. 2010. "Features of English as a Lingua Franca in Academia." Helsinki English Studies 6: 6-28.

McKay, Sandra. 2002. Teaching English as an International Language: Rethinking Goals and Approaches. Oxford: Oxford University Press.

—. 2003. "Toward an Appropriate EIL Pedagogy: Re-examining Common ELT Assumptions." International Journal of Applied Linguistics 13 (1): 1-22. https://doi.org/10.1111/1473-4192.00035.

—. 2012. "Teaching Materials for English as an International Language." In Principles and Practices of Teaching English as an International Language, edited by Aya Matsuda, 70-83. Bristol: Multilingual Matters.

Ministry of Education and Science. 2018. National Curriculum in English for Secondary Schools. Level B2.1 [Online]. Accessed October 8, 2020. https://www.mon.bg/bg/1698.

- 2020. National Curricula in Foreign Languages for Secondary Schools [Online]. Accessed October 8, 2020. https://www.mon.bg/bg/1698.

Modiano, Marko. 2001. "Ideology and the ELT Practitioner." International Journal of Applied Linguistics 11 (2): 159-73. https://doi.org/10.1111/1473-4192.00012.

Nunan, David. 1991. “Communicative Tasks and the Language Curriculum.” TESOL Quarterly 25 (2): 279-95. https://doi.org/10.2307/3587464.

Park, Joo-Kyung, and Mi Kyong Kim. 2014. "Teaching and Learning of EIL in Korean Culture and Context." In The Pedagogy of English as an International Language: Perspectives from Scholars, Teachers, and Students, edited by Roby Marlina and Ram Giri, 47-61. London: Springer International Publishing.

Patev, Pavel, Pavlina Stefanova, Daniela Stoyanova, Yordanka Simeonova, Todor Shopov, Galya Mateva, Palmira Legurska et al. 1993. "Entrance-Exit Level for the School Subject Foreign Language (Primary Schools)." Foreign Language Teaching 4: 2-72.

Patev, Pavel, Pavlina Stefanova, Todor Shopov, Daniela Stoicheva, Yordanka Simeonova, Ivan Tonkin, Palmira Legurska et al. 1995. "Entrance-Exit Level for the School Subject Foreign Language (High Schools and English Medium Schools).” Foreign Language Teaching 4-5: 13-160.

Petkova, Desislava, and Yana Spasova. 2020. Teen Zone: Student's Book for the 11th-12th Grades (B1.1 $C E F$ ). Sofia: Prosveta.

Rangelova, Krassimira, and Lilyana Grozdanova. 2001. Links. Sofia: Prosveta.

Richards, Jack. 2006. Communicative Language Teaching Today. Cambridge: Cambridge University Press.

Seidlhofer, Barbara. 2001. "Closing a Conceptual Gap: The Case for a Description of English as a Lingua Franca.” International Journal of Applied Linguistics 11 (2): 133-58. https://doi.org/10.1111/1473 $-4192.00011$.

—. 2004. "Research Perspectives on Teaching English as a Lingua Franca." Annual Review of Applied Linguistics 24: 209-39. https://doi.org/10.1017/S0267190504000145.

Sharifian, Farzad. 2009. English as an International Language: Perspectives and Pedagogical Issues. Bristol: Multilingual Matters.

Sharifian, Farzad, and Roby Marlina. 2012. "English as an International Language (EIL): An Innovative Academic Program." In Principles and Practices of Teaching English as an International Language, edited by Aya Matsuda, 140-53. Bristol: Multilingual Matters. 
Tella, Seppo, Kaarina Yli-Renko, and Marja Mononen-Aaltonen. 1996. Two Cultures Coming Together. Part 1. Developing Foreign Language Teaching and Teacher Education in Bulgaria. Research Report 155. Helsinki: Department of Teacher Education, University of Helsinki.

Tsvetkova, Nikolina. 2012. "English Language Learning in Secondary Schools and Interculturality." Foreign Language Teaching 39 (3): 236-46.

- 2013. "Developing Intercultural Communicative Competence in the Process of Intensive English Language Teaching in the 8th Grade." Foreign Language Teaching 40 (3): 311-20.

- 2018. English for Communication in the Institutions of the European Union. Sofia: "St. Kliment Ohridski" University Press.

van Ek, Jan, and John Trim. 1991. Threshold Level 1990. Strasbourg: Council of Europe Press.

Zacharias, Nugrahenny, and Christine Manara. 2013. Contextualizing the Pedagogy of English as an International Language: Issues and Tensions. Newcastle upon Tyne: Cambridge Scholars Publishing. 